Original Article

\title{
Prevalence of active HCV infection and genotypic distribution among the general population of district Mardan, Pakistan
}

\author{
Prevalência de infecção HCV ativa a distribuição genotípica entre a população geral do \\ distrito de Mardan, Paquistão
}

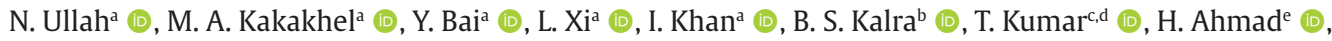 \\ M. Shahf (D, L. Guanlan ${ }^{\mathrm{a}}$ (D) and C. Zhanga* (D) \\ aLanzhou University, School of Life Sciences, MOE Key Laboratory of Cell Activities and Stress Adaptations, Lanzhou, Gansu, China \\ bVirtual University of Pakistan, Department of Bioinformatics and Computational Biology, Lahore, Pakistan \\ ${ }^{\mathrm{c}}$ Ministry of Agriculture, Key Laboratory of Grassland Livestock Industry Innovation, State Key Laboratory of Grassland Agro-Ecosystems, \\ Lanzhou, P.R. China \\ dLanzhou University, College of Pastoral Agriculture Science and Technology, Lanzhou, P.R. China \\ eHazara University Mansehra, Department of Genetics, Mansehra, Pakistan \\ fUniversity of Swat, Centre for Animal Sciences and Fisheries, Swat, Khyber Pakhtunkhwa, Pakistan
}

\begin{abstract}
Hepatitis C virus (HCV) is the serious global public health burden of liver disease. Approximately 170 million people in the world are infected with (HCV). In Pakistan, where the disease has high occurrence rate. The present study envisages an up-to-date prevalence of $\mathrm{HCV}$ and genotypic distribution in the general population of Mardan District, Khyber Pakhtunkhwa (KP), Pakistan. The blood samples from 6,538 individuals including 3,263 males and 3,275 females were analyzed for hepatitis C surface antigen by Immuno-chromatographic test (ICT), Enzyme-linked immunosorbent assay (ELISA), and reverse transcription-polymerase chain reaction (PCR). It was found that 396 (12.13\%) out of 3263 individuals contained antibodies in their blood against HCV, while among the different age groups, the highest incidences of HCV antibodies were found in the $31-40$ age group (11.01\%). The ICT positive samples were further screened by nested PCR to determine the existence of active HCV-RNA. It was identified that $7.11 \%$ (3263) of the total population (6538) tested was positive, among which the 461 (14.07\%) females possessed antibodies in their blood against HCV. Our data showed total HCV infection in the investigated population was 5.78\%. Higher percentage of HCV prevalence was detected in males than females in the age group 31-40 and 41-50. To compare the prevalence of HCV genotypes age-wise in male and female genotype 3a was found most prevalent genotype followed by $1 \mathrm{a}, 2 \mathrm{a}$ and $3 \mathrm{~b}$, respectively.
\end{abstract}

Keywords: HCV, ELISA, PCR, prevalence, Mardan.

\begin{abstract}
Resumo
$\mathrm{O}$ vírus da hepatite $\mathrm{C}(\mathrm{HCV})$ é o grave problema de saúde pública das doenças hepáticas. Aproximadamente 170 milhões de pessoas no mundo estão infectadas com HCV; no Paquistão, a doença tem alto índice de ocorrência. O presente estudo prevê uma prevalência atualizada do HCV e distribuição genotípica na população geral do distrito de Mardan, Khyber Pakhtunkhwa (KP), Paquistão. As amostras de sangue de 6.538 indivíduos, incluindo 3.263 homens e 3.275 mulheres, foram analisadas para o antígeno de superfície da hepatite $C$ por teste imunocromatográfico (ICT), ensaio imunoenzimático (ELISA) e reação em cadeia da polimerase de transcrição reversa (PCR). Verificou-se que 396 (12,13\%) de 3.263 indivíduos continham anticorpos no sangue contra o HCV, enquanto entre as diferentes faixas etárias as maiores incidências de anticorpos anti-HCV foram encontradas na faixa etária de 31 a 40 anos (11,01\%). As amostras positivas para ICT foram posteriormente rastreadas por nested PCR para determinar a existência de HCV-RNA ativo. Identificou-se que 7,11\% (3.263) do total da população (6.538) testada foram positivos, dentre os quais $461(14,07 \%)$ mulheres possuíam anticorpos no sangue contra o HCV. Nossos dados mostraram que a infecção total pelo HCV na população investigada foi de 5,78\%. Maior porcentagem de prevalência de HCV foi detectada em homens do que em mulheres nas faixas etárias de 31-40 e 41-50. Para comparar a prevalência de genótipos de HCV com relação à idade no genótipo masculino e feminino 3a foi encontrado o genótipo mais prevalente seguido por 1a, 2a e 3b, respectivamente.
\end{abstract}

Palavras-chave: HCV, ELISA, PCR, prevalência, Mardan.

*e-mail: chunjiangz122@sina.com.cn

Received: October 26, 2020 - Accepted: December 4, 2020 


\section{Introduction}

$\mathrm{HCV}$ is a chronic infectious disease of the liver caused by a single strand RNA of Hepatitis $C$ virus The virus belongs to the genus hepacivirus specifically affects the liver leading to morbidity and mortality (Bashir et al., 2017; Choo et al., 1989; Tariq et al., 2016). Which were learnt about 15 years later after the discovery of HCV. According to the World health organization (WHO), HCV has infected almost 200 million individuals worldwide and resulted in 350,000 deaths (Tariq et al., 2016). On comparison, the progression of $\mathrm{HCV}$ is more widespread in countries where $\mathrm{HCV}$ prevalence is low such as developing world of West of Europe, North America, and Australia, or intermediate in Japan, Italy, and Spain respectively (Afzal et al., 2016; Ahmed et al., 2006). The major mood of HCV transmission occurred from person to person by blood transfusion, dental and surgical instruments, reused razors, illegal drugs abuses, ear, and nose piercing and tattooing with unsterilized needles, unhygienic or poor sexual practices (Qureshi et al., 2013). Although, the signs and symptoms do not appear obviously. However, HCV infected individuals may suffer from lethal liver cancer/dysfunction and liver injury (Imran et al., 2013).

The general population of Pakistan are infected with $\mathrm{HCV}$, indicating that with the second-highest HCV burden after Egypt (Averhoff et al., 2012; Wedemeyer et al., 2014). The chronic HCV infection depends on several risk factors, encompassing the ethnic group, gender type, host genetic factors, age at the time of infection, immune response, and development of jaundice and viral genotype as well subtypes (Afzal et al., 2014). Replication of Hepatitis C virus by mean of RNA-dependent RNA polymerase is error-prone resulting in the severe heterogenetic and different variant of HCV. As per estimation, 2-10 per nucleotide mutations occur per year (Attaullah et al., 2017; Riaz et al., 2016; Smith et al., 1997). Based on phylogenetic and sequencing analysis, the HCV genome is classified into 7 major and 67 known subtypes and further 20 provision subtypes. Among these genotypes 3 and 1 are world widely distributed (Messina et al., 2015). The identification of genotype is the fundamental measure for the sustainable virological response (SVR), for the selection of therapeutic stratagems and clinical treatment (Zein, 2000). On the ease of availability and low-cost income was an option for treatment of interferon (IFN), high SVR against specific genotypes in Pakistan. The pegylated IFN (PEG-IFN), ribavirin, or various treatment combinations were used (Afzal, 2017; Ahmed et al., 2006; Shah et al., 1997; Yu et al., 2007).

The initial diagnosis of HCV can be achieve by mean of anti-HCV antibodies test or Enzyme-Linked Immunosorbent Assay (ELISA) (Khan et al., 2013). But due to false accuracy results, PCR method holds an advantage over other techniques such as (ELISA), Recombinant Immunoblot assay (RIBA), Enzyme Immunoassay for the Qualitative Detection (EIA), ICT and so on, being a quick and reliable tool to diagnose, identify genotype, and quantify active HCV-RNA.

Previously, rare studies have been undertaken in different regions of Pakistan (Ahmad et al., 2007; Aslam and Aslam, 2001; Kumar et al., 2020, 2017). Thus, urging needs to study the relationship between HCV and population-based on their route of entry, age, and gender with their overall HCV genotypes in Pakistan. Therefore, Mardan is a congested city of Khyber Pakhtunkhwa, Pakistan (Figure 1), was selected due to lack of information and knowledge about the HCV infection, limited health facilities, and other unfavorable environmental conditions. A survey-based prevalence, epidemiology, and genotypic distribution of HCV age base infection in the district Mardan can provides a solid foundation ailment strategy conferring to viral genotype.

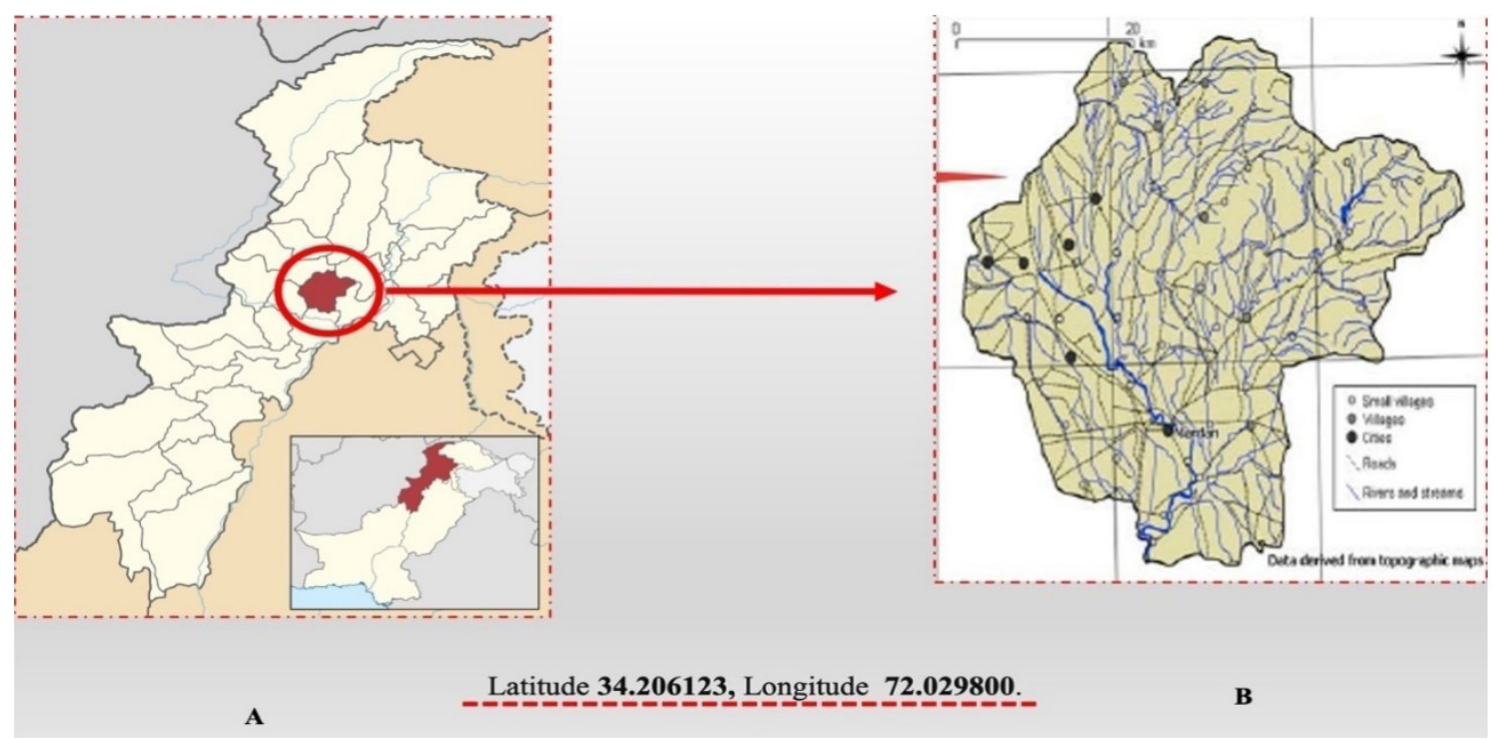

Figure 1. Map of the Khyber Pakhtunkhwa province Pakistan. The district Mardan in encircled, where the present study was conducted for determining the prevalence of active HCV infection and genotypic distribution (Khan et al., 2011): Genotypes of HCV. 


\section{Materials and Methods}

\subsection{Population sampling}

This study was conducted in district Mardan a north-west city of Khyber Pakhtunkhwa province of Pakistan. Blood samples of 6,538 (Males: 3,263 [49.90\%], females: $3275[50.0 \%]$ ) individuals were taken and stored at $4{ }^{\circ} \mathrm{C}$ for serum separation. All the individuals were categorized into different age groups 11-20, 21-30, 31-40, 41-50, 51-60, and 61-70-or above respectively. The population was selected based on visiting the concerned laboratories for diagnosis. The participants younger than 9-10 years were excluded. Data from three years (2017 to 2020), of each patient were taken. All the patient information was exclusively used for research purposes only. The study was approved by the Ethical Committee and collections center or laboratories with the collaboration of the School of Life Sciences, Lanzhou University P.R China, and the Virtual University of Pakistan.

\subsection{Sera-diagnosis via ICT and ELISA}

For anti-HCV antibodies test about 5-ml of the blood was collected in a disposable syringe from the radial vein of patients and stored in sterilized gel tubes. The serum was collected by coagulation of blood and stored at $-20{ }^{\circ} \mathrm{C}$ until next use. Then sera were screened for the presence of anti HCV antibodies using a strip-based technology ICT commercially available from (ACON®, ACON Laboratories Inc., San Diego, CA 92121, USA) and ELISA from S.A. Barcelona Spain as recommended by the manufacturer instructions. The positive samples were further processed for molecular detection and genotypes. The Prevalence rate was determined as frequency based with the help of following Formula 1:

Prevalence $($ as $\%)=100 \times \frac{\text { Number of Positive Samples }}{\text { Number of Total Samples Measured }}$

\subsection{HCV confirmation by PCR and genotyping}

From anti-HCV antibodies positive samples, total RNA was isolated followed by (Kessler et al., 2002), then cDNA was synthesized using gene-specific reverse primers by reverse transcription, using Moloney Murine Leukemia Virus (M-MuLV) reverse transcriptase at $37^{\circ} \mathrm{C}$ for 50 mins. The viral RNA was confirmed through PCR primers (Table 1).
For the genotypic investigation, total RNA from the positive sample was run by (Ohno et al., 1997). Briefly, reverse transcription PCR (RT-PCR) was performed for viral cDNA synthesis using core-gene specific reverse primers, and multiplex-PCR was performed. Nested PCR based two reaction mixtures containing two sets of primers (Table 2 ), were employed. The PCR-thermal cycler conditions were set $94{ }^{\circ} \mathrm{C}$ for 5 mins for pre-denaturation, followed by denaturation at $94{ }^{\circ} \mathrm{C}$ for the $30 \mathrm{~s}$ (30 cycles). The primer annealing temperature was adjusted at $64^{\circ} \mathrm{C}$ for the $30 \mathrm{~s}$; and with an extension of $72{ }^{\circ} \mathrm{C}$ for 30 s, the final cooling temperature of $4{ }^{\circ} \mathrm{C}$ for 10 mins. The same conditions were applied for the nested PCR. Conversely, only primer annealing was carried out at $53{ }^{\circ} \mathrm{C}$. At last, the amplified products of PCR were visualized on the gel documentation system after subjecting to electrophoresis on $2 \%$ agarose gel using with the DNA marker.

\section{Results}

\subsection{Age-specific HCV frequency}

A total of 6,538 participants including 3,263 males and 3,275 female blood samples were collected. All blood samples were tested for the presence of anti-HCV antibodies by using ICT and ELISA. Overall, tested samples were categorized into age groups that fall into seven different age categories 11 to 70 years or above. At first all the male samples were positive by ICT $15.96 \%$ and were further assessed by ELISA. The ELISA results revealed that out of the total number $12.13 \%$ were positive (Table 1 ). The nested PCR assay of the samples positive by either ICT or ELISA revealed that 232 of $7.11 \%$ males are with active HCV RNA in their blood (Table 1). To calculate the age-wise prevalence in males, our results shown that all the age groups were affected while the HCV prevalence fluctuates in different age groups. To find highest incidence rate of $11.01 \%$ was recorded from the age group of $31-40$ years, followed by $7.58 \%$ in the age group of $41-50$. However, the lower HCV incidence of $1.04 \%$ was perceived in the age group of 60-70 years. Contrariwise, no HCV incidence was noted from the age group of 70 or above years (Table 1 ).

Following the same approach, the age-wise prevalence in female gender was also assessed (Table 2). To identify highest incidence rate $7.10 \%$ was observed in the age group

Table 1. Prevalence of active HCV among the different age groups of males as revealed by ICT, ELISA, and PCR tests.

\begin{tabular}{|c|c|c|c|c|c|c|}
\hline Serial No & $\begin{array}{c}\text { Age categories } \\
\text { (years) }\end{array}$ & No. of samples & ICT (Positive) & ELISA (Positive) & $\begin{array}{c}\text { Positive PCR } \\
\text { (Positive) }\end{array}$ & Prevalence (\%) \\
\hline 1 & $11-20$ & 435 & 53 & 29 & 13 & 2.98 \\
\hline 2 & $21-30$ & 492 & 46 & 34 & 26 & 5.28 \\
\hline 3 & $31-40$ & 899 & 155 & 123 & 99 & 11.01 \\
\hline 4 & $41-50$ & 699 & 123 & 114 & 53 & 7.58 \\
\hline 5 & $51-60$ & 623 & 115 & 81 & 40 & 6.42 \\
\hline 6 & $61-70$ & 96 & 25 & 12 & 1 & 1.04 \\
\hline \multirow[t]{2}{*}{7} & 70-or above & 19 & 4 & 3 & 0 & 0 \\
\hline & Total & 3263 & $521(15.96 \%)$ & $396(12.13 \%)$ & $232(7.11 \%)$ & 34.32 \\
\hline
\end{tabular}

${ }^{1}$ Prevalence percentage of positive cases in males: PCR = (7.11\%), ELISA: (12.13\%), and ICT: (15.96\%). 
Table 2. Prevalence of active HCV among the different age groups of females as revealed by ICT, ELISA, and PCR tests.

\begin{tabular}{|c|c|c|c|c|c|c|}
\hline Serial No & $\begin{array}{l}\text { Age categories } \\
\text { (years) }\end{array}$ & No. of samples & ICT (Positive) & $\begin{array}{c}\text { ELISA } \\
\text { (Positive) }\end{array}$ & $\begin{array}{c}\text { Positive PCR } \\
\text { (Positive) }\end{array}$ & Prevalence (\%) \\
\hline 1 & $10-20$ & 398 & 29 & 27 & 13 & 3.26 \\
\hline 2 & $21-30$ & 513 & 46 & 44 & 21 & 4.09 \\
\hline 3 & $31-40$ & 767 & 98 & 67 & 32 & 4.17 \\
\hline 4 & $41-50$ & 859 & 184 & 149 & 61 & 7.10 \\
\hline 5 & $51-60$ & 584 & 75 & 46 & 17 & 2.91 \\
\hline 6 & $61-70$ & 129 & 25 & 15 & 2 & 1.55 \\
\hline \multirow[t]{2}{*}{7} & 70-or above & 25 & 4 & 1 & 0 & 0 \\
\hline & Total & 3275 & $461(14.07 \%)$ & $349(10.65 \%)$ & $146(4.45 \%)$ & 23.09 \\
\hline
\end{tabular}

${ }^{1}$ Prevalence percentage of positive cases in females: PCR: (4.45\%), ELISA: (10.65\%), and ICT: (14.07\%).

of $41-50$ years, followed by $4.17 \%$ in the age group of $31-40$. Similarly to detect lower incidence $1.55 \%$ was observed in the age group of 61-70 years (Table 2). These results revealed that different six age groups were affected significantly. Despite the fact, there were no PCR positive samples were detected in the age groups of 70 or above. Interestingly, it was observed that the age groups, the $41-50$ year the $\mathrm{HCV}$ prevalence was higher in the all adults age group that is 21-40 years. However surprisingly, prevalence was highest in males from 31-40 and in females from 41-50 (Tables 1 and 2). We investigated that $11.01 \%$ of 99 males showed the higher positive PCR results in 31-40 age group for $\mathrm{HCV}$ (Table 1), while the prevalence in females was $7.10 \%$ (61) in the $41-50$ age group (Table 2 ).

Taken together 6,538 contributors' blood was tested for liver function through ICT and ELISA. For HCV antibodies ICT 6,538 results of $15.01 \%$ were positive. The serum samples which were assured affirmative using ICT were furthermore investigated by ELISA. Of which $11.39 \%$ obtained positive. The ELISA positive samples were furthermore sorted for RT-PCR analysis in which $5.78 \%$ samples were confirmed to be active infected of HCV and harbor HCV-RNA (Table 1). The overall data shows the highest prevalence of anti-HCV antibodies tested by ICT, ELISA, and HCV-RNA among the general population of Mardan, KPK Pakistan in males than females (Table 3). The typical gel photograph is presented (Figure 2).

\subsection{Genotypes frequency between male and female}

The prevalence of different genotypes from total HCV-RNA positive samples was further analyzed in the general population. Different HCV genotypes were detected by using allele-specific primers (Ohno et al., 1997). In order, to compare the prevalence of HCV genotypes according to age in male patients were categorized into 7 age groups following the prevalence from (Table 1). HCV genotype 3a was detected $31.94 \%$ of 74 with anti-HCV positive individuals. Moreover, genotype 1 a was observed $17.24 \%$ of 40 , followed by genotype $2 \mathrm{a}$ of $9.48 \%$, and genotype $3 \mathrm{~b}$ was $9.05 \%$, a typical identified genotypes gel photograph (Figure 3). Furthermore, it was observed $17.24 \%$ of 40 tested samples where no genotype PCR band was observed and affirmed as untypable by the present method employed.
Table 3. Overall distribution of the ICT, ELISA, and PCR based HCV results of males and females from Mardan, Khyber Pakhtunkhwa, Pakistan.

\begin{tabular}{lcccl}
\hline Gender & $\begin{array}{c}\text { Total } \\
\text { Samples }\end{array}$ & ICT Result & $\begin{array}{c}\text { ELISA } \\
\text { prevalence }\end{array}$ & PCR \\
\hline Male & 3263 & $15.96 \%$ & $12.13 \%$ & $7.11 \%$ \\
Female & 3275 & $14.07 \%$ & $10.65 \%$ & 4.45 \\
Total & 6538 & $15.01 \%$ & $11.39 \%$ & $5.78 \%$ \\
\hline
\end{tabular}

Correspondingly, also mixed infection of HCV genotypes was detected $15.06 \%$ of 35 (Table 4 ).

In the same way, to compare the age-wise prevalence of HCV genotypes in female patients also categorized into 7 age groups (Table 5 ). These results showed that genotype 3a was detected in female patients $38.35 \%$ of 56 . Thus, these results showed that genotype $3 a$ was significantly more abundant in female patients than males. These shreds of evidence showed that genotype 3a was dominant genotype circulating in general population of Mardan. Furthermore, genotype $1 \mathrm{a}$ ( $16.43 \%$ of 24$)$, and genotype $2 \mathrm{a}$ (9.58\% of 14 ) and genotype $3 \mathrm{~b}$ ( $8.2 \%$ of 12 ) were found in female. Additionally, mixed infection of HCV genotypes 15.08\% of 22 and untypable genotype $12.32 \%$ of 18 was observed in female of Mardan population. Besides these genotypes $5 \mathrm{a}$ and $6 \mathrm{a}$ were not detected in both HCV-RNA positive patients of general population of Mardan KPK.

\subsection{Online data retrieval and its comparison}

To elaborate our investigation a systematic review of the literature was conducted using online available tools, PubMed, PakMedinet, and World Wide Web portal (http://webfoundation.org/). Taken together 18 studies and average prevalence of HCV in terms of the individual province/ cities were compared with our present investigations (Table 6).

Moreover, aiding funds to facilitate the healthcare system and better treatment facilities. Other preventive measures such as public awareness and vaccination programs are extreme need to fortify. The government and health authorities such as national institute of health (NIH) need to re-enforce the management and control strategies. 


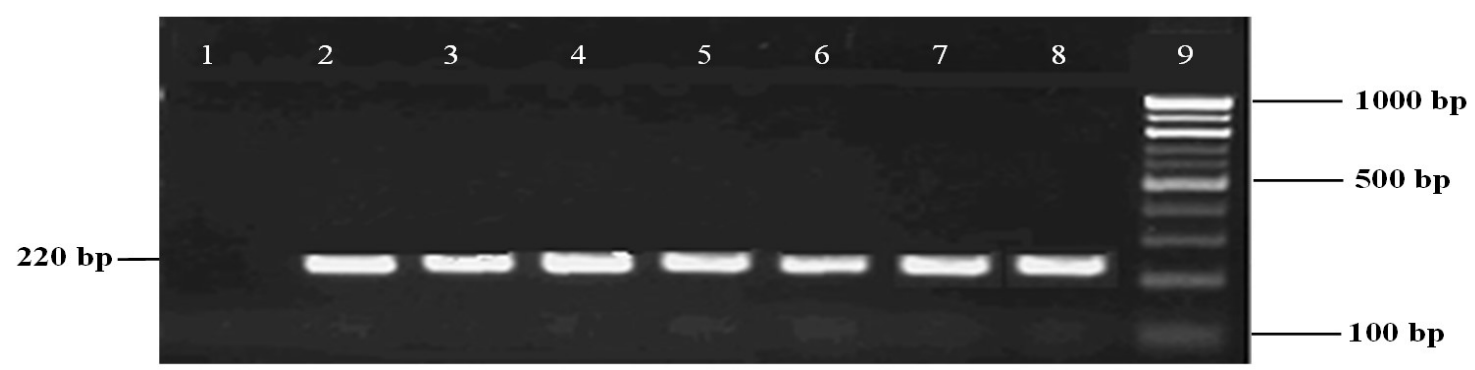

Figure 2. Representative gel photograph of HCV amplified products. Lane 1 represents negative control. HCV, Hepatitis C virus, lanes 2 to 8 are the typical positive samples for active HCV showing expecting 220 bp band of hepatitis C virus and lane, 8 is molecular marker.

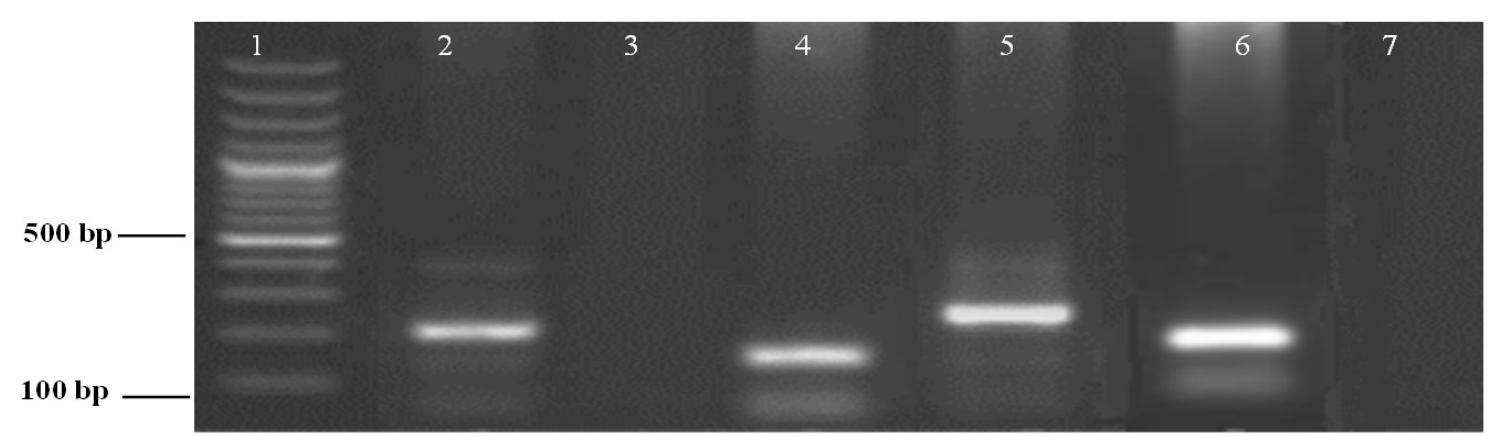

Figure 3. Typical Gels patterns of PCR products of different HCV genotypes identified in Mardan, KPK, Pakistan. Lane $1=$ Molecular marker; Lane 2 = 208 bp HCV genotypes 1a; Lane 3 = untypable genotype; Lane 4 = 176 bp genotypes 3b; Lane $5=232$ bp genotype $3 a$; Lane $6=190$ bp genotype 2a; Lane 7 = negative control.

Table 4. Distribution of active HCV genotypes among the different age groups of males as revealed by PCR.

\begin{tabular}{cccccccccc}
\hline $\begin{array}{c}\text { Serial } \\
\text { No }\end{array}$ & $\begin{array}{c}\text { Age categories } \\
\text { (years) }\end{array}$ & $\mathbf{3 a}$ & $\mathbf{2 a}^{* *}$ & $\mathbf{1 a}^{*}$ & $\mathbf{3 b}^{*}$ & Untypable* $^{*}$ & Mixed $^{*}$ & Total $^{*}$ & $\mathbf{\%}^{*}$ \\
\hline 1 & $10-20$ & 9 & 1 & 1 & 0 & 1 & 1 & 13 & 5.60 \\
2 & $21-30$ & 14 & 2 & 2 & 2 & 4 & 2 & 26 & 11.20 \\
3 & $31-40$ & 24 & 7 & 20 & 12 & 16 & 20 & 99 & 42.67 \\
4 & $41-50$ & 12 & 10 & 12 & 4 & 7 & 8 & 53 & 22.84 \\
5 & $50-60$ & 15 & 2 & 4 & 3 & 12 & 4 & 40 & 17.24 \\
6 & $60-70$ & 0 & 0 & 1 & 0 & 0 & 0 & 1 & 0.431 \\
7 & $71-$ or above & 0 & 0 & 0 & 0 & 0 & 0 & 0 & 0 \\
& Total & $74(31.94 \%)$ & $22(9.48 \%)$ & $40(17.24 \%)$ & $21(9.05 \%)$ & $40(17.24 \%)$ & $35(15.06 \%)$ & 232 \\
\hline
\end{tabular}

a, b: **Genotypes of HCV, *Statistically significant: $(p<0.05)$.

Table 5. Distribution of active HCV genotypes among the different age groups of females as revealed by PCR.

\begin{tabular}{cccccccccc}
\hline S. No & $\begin{array}{c}\text { Age categories } \\
\text { (years) }\end{array}$ & $\mathbf{3 a}^{*}$ & $\mathbf{2 a}^{*}$ & $\mathbf{1 a}^{*}$ & $\mathbf{3 b}^{*}$ & Untypable* $^{*}$ & Mixed $^{*}$ & Total $^{*}$ & \% \\
\hline 1 & $10-20$ & 7 & 0 & 0 & 0 & 1 & 5 & 13 & 8.90 \\
2 & $21-30$ & 7 & 1 & 3 & 2 & 3 & 5 & 21 & 14.38 \\
3 & $31-40$ & 10 & 4 & 8 & 2 & 3 & 5 & 32 & 21.91 \\
4 & $41-50$ & 26 & 9 & 9 & 6 & 6 & 5 & 61 & 41.78 \\
5 & $50-60$ & 5 & 0 & 4 & 2 & 4 & 2 & 17 & 11.64 \\
6 & $60-70$ & 1 & 0 & 0 & 0 & 1 & 0 & 2 & 1.36 \\
7 & $71-$-or above & 0 & 0 & 0 & 0 & 0 & 0 & 0 & 0 \\
& Total & $56(38.35 \%)$ & $14(9.58 \%)$ & $24(16.43 \%)$ & $12(8.21 \%)$ & $18(12.32 \%)$ & $22(15.08 \%)$ & 146 & \\
\hline
\end{tabular}

*Statistically significant: $(p<0.05)$. 
Table 6. Reviewed of literature demonstrating the prevalence of hepatitis C across the different locations of Pakistan from 1999 till now. Each technique of study with its population size and type has been mentioned.

\begin{tabular}{|c|c|c|c|c|c|c|}
\hline S. No & Area Name & $\begin{array}{c}\text { Population } \\
\text { size }\end{array}$ & Population type & Prevalence \% & Technique & Reference \\
\hline 1 & Lahore & 538 & $\begin{array}{l}\text { Pediatric } \\
\text { population }\end{array}$ & $6.7 \%$ & ELISA & Parker et al. (1999) \\
\hline 2 & Rawalpindi & 103858 & blood donors & $3.91 \%$ & ELISA & Khattak et al. (2002) \\
\hline 3 & Quetta/Lahore & 351 & $\begin{array}{l}\text { injection drug } \\
\text { users }\end{array}$ & $88 \%$ & ELISA & Kuo et al. (2006) \\
\hline 4 & Karachi & 4000 & healthy female & $4.5-14 \%$ & ELISA/PCR & Hakim et al. (2008) \\
\hline 5 & Sindh & 5345 & blood donors & $7.5 \%$ & PCR & $\begin{array}{c}\text { Mujeeb and Pearce } \\
\text { (2008) }\end{array}$ \\
\hline 6 & Lahore & 245 & Blood donors & $17.78 \%$ & PCR & Akhtar et al. (2013) \\
\hline 7 & Peshawar & 982 & General population & $12.93 \%$ & CMIA & Ilyas and Ahmad (2014) \\
\hline 8 & Islamabad & 215 & $\begin{array}{l}\text { Hemophilic } \\
\text { patients }\end{array}$ & $36 \%$ & ELISA & Asif et al. (2009) \\
\hline 9 & Bahawalpur & 2239 & Blood donors & $6.7 \%$ & ELISA & Bhatti et al. (2017) \\
\hline 10 & Hyderabad & 3078 & Pregnant women & $4.7 \%$ & PCR & Bibi et al. (2013) \\
\hline 11 & Islamabad & 1977 & $\begin{array}{l}\text { Hospital-based } \\
\text { patients }\end{array}$ & $8.24 \%$ & ELISA & Rana et al. (2020) \\
\hline 12 & Rawalpindi & 673 & Clinical visitor & $30.01 \%$ & $\begin{array}{l}\text { Questionnaire } \\
\text { data }\end{array}$ & Jamil et al. (2020) \\
\hline 13 & Panjab & 8,353 & local community & $79.6 \%$ & PCR & Zafar et al. (2018) \\
\hline 14 & Islamabad & 160,376 & General population & $3.26 \%$ & cross-sectional & Zaheer et al. (2014) \\
\hline 15 & Peshawar & 1978 & General population & $6.21 \%$ & ICT/ PCR & Kumar et al. (2017) \\
\hline 16 & Swat & 185 & infected patients & $62.16 \%$ & PCR & Inamullah et al. (2011) \\
\hline 17 & Mardan & 1419 & Clinical/hospitalize & $8.52 \%$ & ICT/PCR & Ali et al. (2014) \\
\hline 18 & Sindh & 31560 & $\begin{array}{l}\text { The rural area of } \\
\text { Sindh }\end{array}$ & $13.67 \%$ & ELISA/PCR & $\begin{array}{l}\text { Bhatti and Manzoor } \\
\text { (2016) }\end{array}$ \\
\hline
\end{tabular}

This was an initial study and case-control investigation should be conducted in the future.

\section{Discussion}

The emerging infection and diseases pose a serious threat to human health. All these mostly occurred in underdeveloped countries like Pakistan due of limited resources. The new arising pathogens are characterized by a new model of pathogenicity (Khalil et al., 2017). Hepatitis viral rate is alarming in Pakistan (Al Kanaani et al., 2018). The increasing HCV infections precisely depict the prevalence of $\mathrm{HCV}$, and the biogeographic distribution of its genotypes. In this study, 6,538 HCV-suspects were randomly collected from the congested city of Mardan.

The prevalence of HCV has been observed by ICT $15.01 \%$, ELISA $11.39 \%$ and PCR 5.78\%, which comparatively much varies than many cities of Pakistan (Table 1-6), by comparing to Rawalpindi 2.45\% (Masood et al., 2007), Islamabad 5.31\% (Idrees et al., 2008), Buner 5\% (Muhammad and Jan, 2005), Multan 4.06\% (Idrees et al., 2008), Northern areas of Pakistan 25.70\% (Tariq et al., 1999), and Faisalabad 20.89\% (Ahmad et al., 2007). We have also found that the overall percentage was significantly higher in men than women over the last 3 years. This higher prevalence of HCV in male might be due the higher exposure in environment, but HCV is more prevalent among male than females of 2013 and 2017 years (Kumar et al., 2017). Although, epidemiology of HCV exhibit variation from region to region or even within the same population (Wild and Hall, 2000). Such differences of the prevalence of HCV might be associated with different lifestyles, age factors, poor literacy rate and health facilities, low socio-economic status, and lack of awareness (Shah et al., 1997). Considering the age group distribution, the prevalence of HCV infection showed gradually increased among the middle age of 31-50 years. These may reflect that in 31-40 years age group, males have highest prevalence than females while in $41-50$ years age group females were more affected than males. It will be interesting further to find out the factors associated in this gender specification.

Previously studies has shown that the severity, prognosis of disease and response to therapy may vary according to the genotypes (Antaki et al., 2013; Wyles and Gutierrez, 2014). Our data showed that HCV genotype 3a is the most prevalent in the Mardan population, which are corroborated with (Ahmad et al., 2010; Aziz et al., 2013; Khan et al., 2011b). The frequency of genotype 1a was observed in male and female (17.24\% and $16.43 \%$ ) respectively. However, the frequency of the patients infected the method employed with unidentifiable or mix genotype in both genders. In most of previous studies reveal the detection of an unknown/undetermined HCV genotype (Ali et al., 2014; Rauf et al., 2011). These studies specified that identification of these unknown genotype(s), and exploration of its/their possible role for clinical investigations, diagnosis, sequencing and development 
of Hepatitis C, vaccine development and other prevention measures still remains challenging.

Genotype 4a is very rare in Pakistan and also absent in present study, nonetheless, a study on Lahore city in Pakistan identified 4a genotype (Ahmad et al., 2010), in the Middle East (Gower et al., 2014). Genotypes 5a and 6a were also missing in present observations. These studies highlight a important clinical parameters (Ahmad et al., 2010). Moreover, HCV has six different genotypes, which have further subtypes. These genotypes confirmed 30-35\% nucleotide differences in HCV genome (Smith et al., 2014). However, it has been claimed that age is the main and important risk factor for HCV (Kumar et al., 2020, 2017; Mengal et al., 2012). Therefore, based our study different age groups containing HCV infection and even though comparing the different age groups, the adult male population was the most dominant in HCV prevalence at the age of $31-40(11.01 \%)$ followed by females in the age group 41-50 (7.10\%).The highest prevalence of HCV infection existed among middle age of male and old age female with 3a genotype. Therefore, most of the young age individuals remain ignorant about their status of HCV infection. Taken together age has been a main factor in HCV studies, with infection more predominant in older ages of population (Kumar et al., 2020, 2017; Mengal et al., 2012).

The Mardan city was taken as a second model city after Peshawar the capital province of Khyber Pakhtunkhwa, as entire districts have a mixed population (Kumar et al., 2020). Among the Khyber Pakhtunkhwa districts Mardan has been facing basic health requisites problems and suffer from natural disasters including floods, population pressure and earthquakes. However, most of previous findings concern (Table 6), about ICT and ELISA or other non-PCR based (Ahmad et al., 2010). In our findings, RT-PCR depict the more exact picture of active HCV prevalence and genotyping distribution in different age groups of males and females.

Mardan is in the southwest of province Khyber Pakhtunkhwa, Pakistan. The proportion of the urban district is $20.2 \%$ whereas $79.8 \%$ is the rural proportion. A report conducted by Government of Pakistan, compared to urban areas HCV prevalence is more dominant in rural areas (Afridi et al., 2013). Based on our prevalence frequency of different HCV genotyped reported so far lower in females $4.45 \%$ in comparison with males $7.11 \%$. Our investigations suggest that the males community is acquiring HCV infection more rapidly due to maximum exposure to the external environment. On the other hand, barber shaving, Homosexuality may refer to males who have sex with males (MSM), or females who have sex with female (FSF) and use of drugs are common practices in these areas. The arguments are in line for higher occurrence of HCV among males, however in contrast females living house life. Overall, our data support the hypothesis of a homogeneous distribution of HCV infection between the male and female related to various outdoor factors. Similarly, HCV higher prevalence in males followed by females was observed when risk factors regarding hepatitis B and C (Khan et al., 2011a). Furthermore, our finding indicates the dominant genotypes $3 a$ and $1 \mathrm{a}$, among the tested population. These results validate the findings of
(Ahmad et al., 2010; Kumar et al., 2017), reported that $59.9 \%$ and $16.5 \%$ of individuals were infected with $3 a$ and 1a genotypes, both these being higher percentages than the other genotypes detected. Genotype $3 a$ of $34.1 \%$ as the most prevalent genotype in district Swat, followed by $2 \mathrm{a}(8.1 \%), 3 \mathrm{~b}(7 \%), 1 \mathrm{a}(5.4 \%)$ and mixed genotype $7.6 \%$ (Inamullah et al., 2011). Another study of $49.5 \%$ prevalence genotype 3a described in district Swat (Ahmad et al., 2009). To mitigate the risks associated with HCV infection, it is important to understand the interactions of pathogen-hostenvironment and monitor the molecular evolution and genomic surveillance.

Based on our visual investigation, most of the patients associated with low economic status and visited by other local medical practitioners. Lack of emergency medical services and initial help to victims are commonly practiced by untrained worker might be another major cause hepatitis C (Bukhari, 2013). Use of no proper sterilization and contaminated equipment may represent another possible reason for high prevalence. Besides this sharing personal possession such as shaving razors, nail cutters, the needle used for ear and nose piercing, toothbrushes, and personal close or/and transgender sexual contact with an infected person (Qureshi et al., 2013).

The results of our study showed prevalence and distribution of HCV genotypes varies with age. For example, genotype 3a was more common in male the ages 31-40, while it was more prevalent in female between ages 41-50. To our knowledge, it is the comprehensive report to evaluates the distribution of genotypes of HCV in Mardan, but it has some limitations, such as subtype with a relatively small sample size and a selection bias is possible given the use of the data from a multiple laboratory. But our study may be helpful for understanding the genotype distribution of HCV in Mardan and can provide important information about HCV prevalence among different ages and sexes. However, Khyber Pakhtunkhwa may not have much strength or capacity to mitigate these problems itself immediately. By so far, great push up efforts are required by the national/international community to reduce the existing threat.

\section{Conclusion}

In conclusion, $\mathrm{HCV}$ prevalence and genotype distribution has a certain relationship with different age and gender. We found that HCV 3a is a predominant genotype followed by 1a, 2a, and 3b in Mardan. Further studies are needed to collect bigger samples to estimate the different epidemiology of the HCV genotypes. As males are more frequently prone to high-risk than female also indicating that the infection is more proliferated between the adult group either males or females. To control HCV disease, there is a dire need to design a treatment achieving maximum control with minimal hostile effects. Major awareness events should be launched by Government and Semi government authorities or non-government organizations (NGOs), ample use of vaccine and other preventive measures to cease the outspread. 


\section{Acknowledgements}

The authors express their sincere gratitude to the local Medical Centers and Hospitals of Mardan, Khyber Pakhtunkhwa, Pakistan, for granting this award for their research. Also extend esteemed thanks to all the concerned friends, doctor clinicians/patients for their cooperation as well as their support throughout this study. Authors are also very grateful for the Chinese Government Scholarship Council for the award of Doctoral studies.

The study was funded by Jiangsu Science and Technology Major Project (No. BA2016036), Lanzhou Science and Technology Funds (No. 2015-3-81), and Gansu Science and Technology Major Project (No. 17ZD2FA009).

\section{References}

AFRIDI, S.Q., ZAHID, M.N., SHABBIR, M.Z., HUSSAIN, Z., MUKHTAR, N., TIPU, M.Y., AKHTAR, F. and YAQUB, T., 2013. Prevalence of HCV genotypes in district Mardan. Virology Journal, vol. 10, no. 1, pp. 90. http://dx.doi.org/10.1186/1743-422X-10-90. PMid:23514695.

AFZAL, M.S., 2017. Hepatitis C virus and interferon-free antiviral therapeutics revolution: implications for Pakistan. Viral Immunology, vol. 30, no. 4, pp. 252-257. http://dx.doi. org/10.1089/vim.2016.0164. PMid:28118096.

AFZAL, M.S., AHMED, T. and ZAIDI, N.U., 2014. Comparison of HCV prevalence in pakistan and iran; an insight into future. Hepatitis Monthly, vol. 14, no. 1, pp. e11466. http://dx.doi.org/10.5812/ hepatmon.11466. PMid:24497874.

AFZAL, M.S., SHAH, Z.H. and AHMED, H., 2016. Recent HCV genotype changing pattern in the Khyber Pakhtunkhwa province of Pakistan; is it pointing out a forthcoming problem? The Brazilian Journal of Infectious Diseases, vol. 20, no. 3, pp. 312-313. http:// dx.doi.org/10.1016/j.bjid.2015.12.011. PMid:26963150.

AHMAD, A., AHMAD, B., ALI, A. and AHMAD, Y., 2009. Seroprevalence of HBsAg and anti-HCV in general healthy population of Swat district with frequency of different HCV Genotypes. Pakistan Journal of Medical Sciences, vol. 25, pp. 744-748.

AHMAD, N., ASGHER, M., SHAFIQUE, M. and QURESHI, J.A., 2007. An evidence of high prevalence of Hepatitis $\mathrm{C}$ virus in Faisalabad, Pakistan. Saudi Medical Journal, vol. 28, no. 3, pp. 390-395. PMid:17334466.

AHMAD, W., IJAZ, B., JAVED, F.T., JAHAN, S., SHAHID, I., KHAN, F.M. and HASSAN, S., 2010. HCV genotype distribution and possible transmission risks in Lahore, Pakistan. World Pakistan Journal of Gastroenterology, vol. 16, no. 34, pp. 4321-4328. http://dx.doi. org/10.3748/wjg.v16.i34.4321. PMid:20818816.

AHMED, S.I., MAHMUD, M.R., KHAN, N.Y., NASEEMULLAH, M. and HANIF, M., 2006. Pegylated interferon and ribavirin in HCV genotype 3 detectable patients after 12 weeks of conventional interferon-ribavirin treatment. Pakistan Journal of Gastroenterology, vol. 20, pp. 58-62.

AKHTAR, A.M., KHAN, M.A., IJAZ, T., IQBAL, Z., RANA, M.Y., MAQBOOL, A. and REHMAN, A., 2013. Seroprevalence and determinants of hepatitis-C Virus infection in blood donors of Lahore, Pakistan. Pakistan Journal of Zoology, vol. 45, no. 1, pp. 1-7.

AL KANAANI, Z., MAHMUD, S., KOUYOUMJIAN, S.P. and ABURADDAD, L.J., 2018. The epidemiology of hepatitis $C$ virus in Pakistan: systematic review and meta-analyses. Royal Society Open Science, vol. 5, no. 4, 180257. http://dx.doi.org/10.1098/ rsos.180257. PMid:29765698.
ALI, S., AHMAD, A., KHAN, R.S., KHAN, S., HAMAYUN, M., KHAN, S.A., IQBAL, A., KHAN, A.A., WADOOD, A., UR RAHMAN, T. and BAIG, A.H., 2014. Genotyping of HCV RNA reveals that $3 \mathrm{a}$ is the most prevalent genotype in mardan, pakistan. Advances in Virology, vol. 2014, 606201. http://dx.doi.org/10.1155/2014/606201. PMid:24715902.

ANTAKI, N., BIBERT, S., KEBBEWAR, K., ASAAD, F., BAROUDI, O., ALIDEEB, S., HADAD, M., ABBOUD, D., SABAH, H., BOCHUD, P.-Y. and NEGRO, F., 2013. IL28B polymorphisms predict response to therapy among chronic hepatitis $\mathrm{C}$ patients with $\mathrm{HCV}$ genotype 4. Journal of Viral Hepatitis, vol. 20, no. 1, pp. 59-64. http:// dx.doi.org/10.1111/j.1365-2893.2012.01621.x. PMid:23231085.

ASIF, N., ZAFAR, T., HASSAN, K. and NASEEM, L., 2009. Seroprevalence anti HCV antibodies, HCV-RNA and its genotypes among patients of hemophilia, at Hemophilia Treatment Centre Pakistan Institute of Medical Sciences, Islamabad. International Journal of Pathology, vol. 7, pp. 84-87.

ASLAM, M. and ASLAM, J., 2001. Seroprevalence of the antibody to hepatitis $C$ in select groups in the Punjab region of Pakistan. Journal of Clinical Gastroenterology, vol. 33, no. 5, pp. 407411. http://dx.doi.org/10.1097/00004836-200111000-00013. PMid:11606859.

ATTAULLAH, S., KHAN, S. and ZAHID, M., 2017. Heterogeneous distribution of $\mathrm{HCV}$ genotypes and growing menace of mixed $\mathrm{HCV}$ infection in blood recipients in Khyber Pakhtunkhwa. The Brazilian Journal of Infectious Diseases, vol. 21, no. 4, pp. 489-490. http://dx.doi.org/10.1016/j.bjid.2016.12.009. PMid:28282507.

AVERHOFF, F.M., GLASS, N. and HOLTZMAN, D., 2012. Global burden of hepatitis C: considerations for healthcare providers in the United States. Clinical Infectious Diseases, vol. 55, suppl. 1, pp. S10-S15. http://dx.doi.org/10.1093/cid/cis361. PMid:22715208.

AZIZ, H., RAZA, A., MURTAZA, S., WAHEED, Y., KHALID, A., IRFAN, J., SAMRA, Z. and ATHAR, M.A., 2013. Molecular epidemiology of hepatitis $C$ virus genotypes in different geographical regions of Punjab Province in Pakistan and a phylogenetic analysis. International Journal of Infectious Diseases, vol. 17, no. 4, pp. e247-e253. http://dx.doi.org/10.1016/j.ijid.2012.09.017. PMid:23183233.

BASHIR, T., ASIM, M., AHSAN, M., ZAFAR, M.Z. and HUSSAIN, K., 2017. A case report: patient with the history of hepatitis $C$ virus. Journal of Antivirals \& Antiretrovirals, vol. 9, no. 2, pp. 55-57. http://dx.doi.org/10.4172/1948-5964.1000162.

BHATTI, K.A., LASHARI, M.K. and FATIMA, H., 2017. Seroprevalence of anti HCV, Hbsag, HIV, and VDRL among donors at blood transfusion unit, THQ Hospital Ahmed Pur East, District Bahawalpur, Punjab, Pakistan. International Journal of Research, vol. 4, no. 6, pp. 1623-1636.

BHATTI, S. and MANZOOR, S., 2016. Molecular epidemiology and clinical features of Hepatitis C Virus (HCV) in epidemic areas of Interior Sindh, Pakistan. Pakistan Journal of Medical Sciences, vol. 32, no. 5, pp. 1279-1282. http://dx.doi.org/10.12669/ pjms.325.10429. PMid:27882036.

BIBI, S., DARS, S., ASHFAQ S., ARA QAZI, R. and AKHUND, S., 2013. Seroprevalence and risk factors for hepatitis $C$ virus (HCV) infection in pregnant women attending public sector tertiary care hospital in Hyderabad Sindh. Pakistan Journal of Medical Sciences, vol. 29, no. 2, pp. 505-508. http://dx.doi.org/10.12669/ pjms.292.3211. PMid:24353565.

BUKHARI, M.M., 2013. Standard interferon and ribavirin response in patients with chronic hepatitis C. Rawalpindi Journal of Rawalpindi Medical College, vol. 17, pp. 297-299.

CHOO, Q.-L., KUO, G., WEINER, A.J., OVERBY, L.R., BRADLEY, D.W. and HOUGHTON, M., 1989. Isolation of a cDNA clone derived from 
a blood-borne non-A, non-B viral hepatitis genome. Science, vol. 244, no. 4902, pp. 359-362. http://dx.doi.org/10.1126/ science.2523562. PMid:2523562.

GOWER, E., ESTES, C., BLACH, S., RAZAVI-SHEARER, K. and RAZAVI, H., 2014. Global epidemiology and genotype distribution of the hepatitis C virus infection. Journal of Hepatology, vol. 61, no. 1, suppl., pp. S45-S57. http://dx.doi.org/10.1016/j.jhep.2014.07.027. PMid:25086286.

HAKIM, S.T., KAZMI, S.U. and BAGASRA, O., 2008. Seroprevalence of hepatitis $B$ and $C$ genotypes among young apparently healthy females of Karachi-Pakistan. The Libyan Journal of Medicine, vol. 3, no. 2, pp. 66-70. http://dx.doi.org/10.3402/ljm.v3i2.4760. PMid:21499460.

IDREES, M., LAL, A., NASEEM, M. and KHALID, M., 2008. High prevalence of hepatitis $C$ virus infection in the largest province of Pakistan. Journal of Digestive Diseases, vol. 9, no. 2, pp. 95-103. http://dx.doi.org/10.1111/j.1751-2980.2008.00329.x. PMid:18419643.

ILYAS, M. and AHMAD, I., 2014. Chemiluminescent microparticle immunoassay based detection and prevalence of HCV infection in district Peshawar Pakistan. Virology Journal, vol. 11, no. 1, pp. 127. http://dx.doi.org/10.1186/1743-422X-11-127. PMid:25016473.

IMRAN, M., MANZOOR, S., ASHRAF, J., KHALID, M., TARIQ, M., KHALIQ H.M. and AZAM, S., 2013. Role of viral and host factors in interferon based therapy of hepatitis C virus infection. Virology Journal, vol. 10, no. 1, pp. 299. http://dx.doi.org/10.1186/1743422X-10-299. PMid:24079723.

INAMULLAH, I., IDREES, M., AHMED, H., ALI, M., ALI, L. and AHMED, A., 2011. Hepatitis $C$ virus genotypes circulating in district Swat of Khyber Pakhtoonkhaw, Pakistan. Virology Journal, vol. 8, pp. 16. PMid:21235746.

JAMIL, Z., WAHEED, Y., AHSAN, O., NAJMI, M.H. and YOUSUF, H., 2020. Familial Clustering of Hepatitis C Virus in Pakistani Population. Journal of Medical Virology, vol. 92, no. 12, pp. 34993506. http://dx.doi.org/10.1002/jmv.25926. PMid:32320089.

KESSLER, H.H., CLARICI, A.M.K., STELZL, E., MÜHLBAUER, G., DAGHOFER, E., SANTNER, B.I., MARTH, E. and STAUBER, R.E., 2002. Fully automated detection of hepatitis $C$ virus RNA in serum and whole-blood samples. Clinical and Diagnostic Laboratory Immunology, vol. 9, no. 6, pp. 1385-1388. http:// dx.doi.org/10.1128/cdli.9.6.1385-1388.2002. PMid:12414781.

KHALIL, A.T., ALI, M., TANVEER, F., OVAIS, M., IDREES, M., SHINWARI, Z.K. and HOLLENBECK, J.E., 2017. Emerging viral infections in Pakistan: issues, concerns, and future prospects. Health Security, vol. 15, no. 3, pp. 268-281. http://dx.doi.org/10.1089/ hs.2016.0072. PMid:28636447.

KHAN, A., TAREEN, A.M., IKRAM, A., RAHMAN, H., WADOOD, A., QASIM, M. and KHAN, K., 2013. Prevalence of HCV among the young male blood donors of Quetta region of Balochistan, Pakistan. Virology Journal, vol. 10, no. 1, pp. 83. http://dx.doi. org/10.1186/1743-422X-10-83. PMid:23497435.

KHAN, M., HUSSAIN, F. and MUSHARAF, S., 2011. A fraction of fresh water algae of Kalpani stream and adjoining area of district Mardan, Pakistan. International Journal of Biosciences, vol. 1, pp. 2220-6655.

KHAN, S., ATTAULLAH, S., ALI, I., AYAZ, S., KHAN, S.N., SIRAJ, S. and KHAN, J., 2011a. Rising burden of Hepatitis C Virus in hemodialysis patients. Virology Journal, vol. 8, no. 1, pp. 438 http://dx.doi.org/10.1186/1743-422X-8-438. PMid:21920054.

KHAN, S., ATTAULLAH, S., AYAZ, S., KHAN, S.N., SHAMS, S., ALI, I., BILAL, M. and SIRAJ, S., 2011b. Molecular epidemiology of HCV among health care workers of Khyber Pakhtunkhwa. Virology
Journal, vol. 8, no. 1, pp. 105. http://dx.doi.org/10.1186/1743422X-8-105. PMid:21385397.

KHATTAK, M.F., SALAMAT, N., BHATTI, F.A. and QURESHI, T.Z., 2002. Seroprevalence of hepatitis B, C and HIV in blood donors in northern Pakistan. JPMA. The Journal of the Pakistan Medical Association, vol. 52, no. 9, pp. 398-402. PMid:12532573.

KUMAR, T., AHMAD, N., HAYAT, M.K., GAO, B.-X., FAISAL, S., ILAHI, N., ALI, B., ZADA, S. and SAJJAD, W., 2017. Prevalence and genotypic distribution of hepatitis $C$ virus in Peshawar KPK, Pakistan. Hayati Journal of Biosciences, vol. 24, no. 1, pp. 22-25. http://dx.doi.org/10.1016/j.hjb.2017.04.002.

KUMAR, T., ZADA, S., IRFAN, M., BATOOL, H. and SAJJAD, W., 2020. Serological Prevalence of Hepatitis B Virus in Peshawar, Khyber Pakhtunkhwa, Pakistan. Pakistan Journal of Zoology, vol. 52, no. 2, pp. 525. http://dx.doi.org/10.17582/journal.pjz/20190213140254.

KUO, I., UL-HASAN, S., GALAI, N., THOMAS, D.L., ZAFAR, T., AHMED, M.A. and STRATHDEE, S.A., 2006. High HCV seroprevalence and HIV drug use risk behaviors among injection drug users in Pakistan. Harm Reduction Journal, vol. 3, no. 1, pp. 26. http:// dx.doi.org/10.1186/1477-7517-3-26. PMid:16914042.

MASOOD, R., SARDAR, M.A. and MALLHI, A.A., 2007. Seroprevalence of hepatitis B and C among the healthy blood donors at Fauji Foundation Hospital, Rawalpindi. Pakistan Journal of Medical Sciences, vol. 23, pp. 64-67.

MENGAL, M.A., ABBAS, F., MENGAL, M.A., SHAFEE, M., BABAR, S. and ATIQUE, A., 2012. Passive surveillance of anti-hepatitis $C$ virus antibodies in human subjects of four medical units of Balochistan, Pakistan. International Journal of Agriculture and Biology, vol. 14, no. 4, pp. 585-589.

MESSINA, J.P., HUMPHREYS, I., FLAXMAN, A., BROWN, A., COOKE, G.S., PYBUS, O.G. and BARNES, E., 2015. Global distribution and prevalence of hepatitis C virus genotypes. Hepatology, vol. 61, no. 1, pp. 77-87. http://dx.doi.org/10.1002/hep.27259. PMid:25069599.

MUHAMMAD, N. and JAN, M.A., 2005. Frequency of hepatitis" C" in Buner, NWFP. Journal of the College of Physicians and Surgeons, vol. 15, no. 1, pp. 11-14. PMid:15670516.

MUJEEB, S.A. and PEARCE, M.S., 2008. Temporal trends in hepatitis $B$ and $C$ infection in family blood donors from interior Sindh, Pakistan. BMC Infectious Diseases, vol. 8, no. 1, pp. 43. http:// dx.doi.org/10.1186/1471-2334-8-43. PMid:18402660.

OHNO, O., MIZOKAMI, M., WU, R.-R., SALEH, M.G., OHBA, K., ORITO, E., MUKAIDE, M., WILLIAMS, R. and LAU, J.Y., 1997. New hepatitis $\mathrm{C}$ virus (HCV) genotyping system that allows for identification of HCV genotypes 1a, 1b, 2a, 2b, 3a, 3b, 4, 5a, and 6a. Journal of Clinical Microbiology, vol. 35, no. 1, pp. 201-207. http://dx.doi. org/10.1128/jcm.35.1.201-207.1997. PMid:8968908.

PARKER, S.P., KHAN, H.I. and CUBITT, W.D., 1999. Detection of antibodies to hepatitis $\mathrm{C}$ virus in dried blood spot samples from mothers and their offspring in Lahore, Pakistan. Journal of Clinical Microbiology, vol. 37, no. 6, pp. 2061-2063. http:// dx.doi.org/10.1128/JCM.37.6.2061-2063.1999. PMid:10325381.

QURESHI, H., MOHAMUD, B.K., ALAM, S.E., ARIF, A. and AHMED, W., 2013. Treatment of hepatitis $B$ and $C$ through national programme: an audit.JPMA. The Journal of the Pakistan Medical Association, vol. 63, no. 2, pp. 220-224. PMid:23894899.

RANA, N.A., MUNIR, B., HUSSAIN, N., IMTIAZ, N., GONDAL, A. and PARVAIZ, F., 2020. Seroprevalence, biochemical investigation and risk factor assessment for HBV \& HCV Infection in Hospital Based Patients of Islamabad, Pakistan. Journal of Bioresource Management, vol. 7, no. 2, pp. 1-11. http://dx.doi.org/10.35691/ JBM.0202.0127. 
RAUF, A., NADEEM, M.S., ALI, A., IQBAL, M., MUSTAFA, M., MUZAMMAL LATIF, M., LATIF, M.Z., AHMED, N. and SHAKOORI, A.R., 2011. Prevalence of hepatitis $B$ and $C$ in internally displaced persons of war against terrorism in Swat, Pakistan. European Journal of Public Health, vol. 21, no. 5, pp. 638-642. http://dx.doi. org/10.1093/eurpub/ckq084. PMid:20601693.

RIAZ, S., BASHIR, M.F., HAIDER, S. and RAHID, N., 2016. Association of genotypes with viral load and biochemical markers in HCVinfected Sindhi patients. Brazilian Journal of Microbiology, vol. 47, no. 4, pp. 980-986. PMid:27528079.

SHAH, H.A., JAFRI, W., MALIK, I., PRESCOTT, L. and SIMMONDS, P., 1997. Hepatitis C virus (HCV) genotypes and chronic liver disease in Pakistan. Journal of Gastroenterology and Hepatology, vol. 12, no. 11, pp. 758-761. http://dx.doi.org/10.1111/j.1440-1746.1997. tb00366.x. PMid:9430043.

SMITH, D.B., BUKH, J., KUIKEN, C., MUERHOFF, A.S., RICE, C.M., STAPLETON, J.T. and SIMMONDS, P., 2014. Expanded classification of hepatitis $C$ virus into 7 genotypes and 67 subtypes: updated criteria and genotype assignment web resource. Hepatology, vol. 59, no. 1, pp. 318-327. http://dx.doi.org/10.1002/hep.26744. PMid:24115039.

SMITH, D.B., YAP, P.L., SIMMONDS, P., LAWLOR, E., POWER, J., PATHIRANA, S. and DAVIDSON, F., 1997. The origin of hepatitis C virus genotypes. The Journal of General Virology, vol. 78, no. Pt 2, pp. 321-328. http://dx.doi.org/10.1099/0022-1317-78-2321. PMid:9018053.

TARIQ, S., BATOOL, Z., JAHANZEB, V., TARIQ, Q.-A. and DURRANI, S.H. 2016. Hepatitis C virus genotype distribution amongst HCV positive patients present ING at a private tertiary care hospital of Peshawar, Khyber Pakhtunkhwa. Journal of Rehman Medical Institute, vol. 2, no. 2, pp. 33-39.

TARIQ, W.U., HUSSAIN, A.B., KARAMAT, K.A., GHANI, E., HUSSAIN, T. and HUSSAIN, S., 1999. Demographic aspects of hepatitis $C$ in northern Pakistan.JPMA. The Journal of the Pakistan Medical Association, vol. 49, no. 8, pp. 198-201. PMid:10641504.

WEDEMEYER, H., DUBERG, A.S., BUTI, M., ROSENBERG, W.M., FRANKOVA, S., ESMAT, G., ÖRMECI, N., VAN VLIERBERGHE, H., GSCHWANTLER, M., AKARCA, U., ALEMAN, S., BALIK, I., BERG, T., BIHL, F., BILODEAU, M., BLASCO, A.J., BRANDÃO MELLO, C.E., BRUGGMANN, P., CALINAS, F., CALLEJA, J.L., CHEINQUER, H., CHRISTENSEN, P.B., CLAUSEN, M., COELHO, H.S., CORNBERG, M., CRAMP, M.E., DORE, G.J., DOSS, W., EL-SAYED, M.H., ERGÖR, G., ESTES, C., FALCONER, K., FÉLIX, J., FERRAZ, M.L., FERREIRA, P.R., GARCÍA-SAMANIEGO, J., GERSTOFT, J., GIRIA, J.A., GONÇALES
JUNIOR, F.L., GUIMARÃES PESSÔA, M., HÉZODE, C., HINDMAN, S.J., HOFER, H., HUSA, P., IDILMAN, R., KÅBERG, M., KAITA, K.D., KAUTZ, A., KAYMAKOGLU, S., KRAJDEN, M., KRARUP, H., LALEMAN, W., LAVANCHY, D., LÁZARO, P., MARINHO, R.T., MAROTTA, P., MAUSS, S., MENDES CORREA, M.C., MORENO, C., MÜLLHAUPT, B., MYERS, R.P., NEMECEK, V., ØVREHUS, A.L., PARKES, J., PELTEKIAN, K.M., RAMJI, A., RAZAVI, H., REIS, N., ROBERTS, S.K., ROUDOT-THORAVAL, F., RYDER, S.D., SARMENTOCASTRO, R., SARRAZIN, C., SEMELA, D., SHERMAN, M., SHIHA, G.E., SPERL, J., STÄRKEL, P., STAUBER, R.E., THOMPSON, A.J., URBANEK, P., VAN DAMME, P., VAN THIEL, I., VANDIJCK, D., VOGEL, W., WAKED, I., WEIS, N., WIEGAND, J., YOSRY, A., ZEKRY, A., NEGRO, F., SIEVERT, W. and GOWER, E., 2014. Strategies to manage hepatitis C virus (HCV) disease burden. Journal of Viral Hepatitis, vol. 21, suppl. 1, pp.60-89. http://dx.doi.org/10.1111/ jvh.12249. PMid:24713006.

WILD, C.P. and HALL, A.J., 2000. Primary prevention of hepatocellular carcinoma in developing countries. Mutat. Res. Mutation Research, vol. 462, no. 2-3, pp. 381-393. http://dx.doi.org/10.1016/S13835742(00)00027-2. PMid:10767647.

WYLES, D.L. and GUTIERREZ, J.A., 2014. Importance of HCV genotype 1 subtypes for drug resistance and response to therapy.Journal of Viral Hepatitis, vol. 21, no. 4, pp. 229-240. http://dx.doi. org/10.1111/jvh.12230. PMid:24597691.

YU, J., WANG, G., SUN, L., LI, X. and LI, S., 2007. Predictive value of rapid virological response and early virological response on sustained virological response in HCV patients treated with pegylated interferon $\alpha-2 a$ and ribavirin. Journal of Gastroenterology and Hepatology, vol. 22, no. 6, pp. 832836. http://dx.doi.org/10.1111/j.1440-1746.2007.04904.x. PMid:17565637.

ZAFAR, A., IMRAN, M., ZAHOOR, S., SHAH, Z.H., ALI, M. and AFZAL, M.S., 2018. Prevalence and treatment of untypable HCV variants in different districts of Punjab, Pakistan. Viral Immunology, vol. 31, no. 6, pp. 426-432. http://dx.doi.org/10.1089/vim.2017.0167. PMid:29920175.

ZAHEER, H.A., SAEED, U., WAHEED, Y., KARIMI, S. and WAHEED, U., 2014. Prevalence and trends of hepatitis B, hepatitis C and human immunodeficiency viruses among blood donors in Islamabad, Pakistan 2005-2013. Journal of Blood Disorders \& Transfusion, vol. 5, no. 6, 1000217.

ZEIN, N.N., 2000. Clinical significance of hepatitis C virus genotypes. Clinical Microbiology Reviews, vol. 13, no. 2, pp. 223-235. http:// dx.doi.org/10.1128/CMR.13.2.223. PMid:10755999. 